\title{
Field comparison of real-time polymerase chain reaction and bacterial culture for identification of bovine mastitis bacteria
}

\author{
M. T. Koskinen, ${ }^{, 1,2}$ G. J. Wellenberg,† O. C. Sampimon, $†$ J. Holopainen, ${ }^{\star}$ A. Rothkamp, $†$ L. Salmikivi, ${ }^{*}$ \\ W. A. van Haeringen,ł T. J. G. M. Lam,† and S. Pyörälä§ \\ *Finnzymes Oy, Keilaranta 16A, 02150 Espoo, Finland \\ †GD Animal Health Service, Deventer, the Netherlands \\ fDr. Van Haeringen Laboratorium B.V., Wageningen, the Netherlands. \\ §University of Helsinki, Faculty of Veterinary Medicine, Department of Production Animal Medicine, Saarentaus, Finland
}

\begin{abstract}
Fast and reliable identification of the microorganisms causing mastitis is important for management of the disease and for targeting antimicrobial treatment. Methods based on PCR are being used increasingly in mastitis diagnostics. Comprehensive field comparisons of PCR and traditional milk bacteriology have not been available. The results of a PCR kit capable of detecting 11 important etiological agents of mastitis directly from milk in $4 \mathrm{~h}$ were compared with those of conventional bacterial culture $(48 \mathrm{~h})$. In total, 1,000 quarter milk samples were taken from cows with clinical or subclinical mastitis, or from clinically healthy quarters with low somatic cell count (SCC). Bacterial culture identified udder pathogens in $600 / 780(77 \%)$ of the clinical samples, whereas PCR identified bacteria in 691/780 $(89 \%)$ of the clinical samples. The PCR analysis detected major pathogens in a large number of clinical samples that were negative for the species in culture. These included 53 samples positive for Staphylococcus aureus by PCR, but negative by culture. A total of 137 samples from clinical mastitis, 5 samples from subclinical mastitis, and 1 sample from a healthy quarter were positive for 3 or more bacterial species in PCR, whereas culture identified 3 or more species in 60 samples from clinical mastitis. Culture identified a species not targeted by the PCR test in 44 samples from clinical mastitis and in 9 samples from subclinical mastitis. Low SCC samples provided a small number of positive results both in culture $(4 / 93 ; 4.3 \%)$ and by PCR $(7 / 93 ; 7.5 \%)$. In conclusion, the PCR kit provided several benefits over conventional culture, including speed, automated interpretation of results, and increased sensitivity. This kit holds much promise as a tool to complement traditional
\end{abstract}

Received February 12, 2010.

Accepted September 2, 2010.

${ }^{1}$ Corresponding author: mikko.t.koskinen@thermofisher.com

${ }^{2}$ Thermo Fisher Scientific, Keilaranta 16A, 02150 Espoo, Finland. methods in identification of pathogens. In conventional mastitis bacteriology, a sample with 3 or more species is considered contaminated, and resampling of the cow is recommended. Further study is required to investigate how high sensitivity of PCR and its quantitative features can be applied to improve separation of relevant udder pathogens from likely contaminants in samples where multiple species are detected. Furthermore, increasing the number of species targeted by the PCR test would be advantageous.

Key words: mastitis, real-time PCR, pathogen, bacterial culture

\section{INTRODUCTION}

Intramammary infections lead to a significant decrease in milk yield and quality and represent a major economical and health problem to the dairy industry worldwide (Halasa et al., 2009). Intramammary infections can result in clinical mastitis, in which systemic signs, local signs, and changes in milk appearance can occur. Mastitis can remain subclinical, where the cow shows no clinical signs, but the SCC of milk is increased (IDF, 1999).

Reliable identification of the bacteria responsible for mastitis is important for disease management in the herd and for targeting antimicrobial treatment (NMC, 1996). Currently, bacterial culture is the goldstandard method for identification of mastitis-causing microorganisms. Conventional culture is slow, requiring from 24 to $48 \mathrm{~h}$ (Hogan et al., 1999). In clinical mastitis, a faster diagnosis would often be preferable to enable treatment as soon as possible. Delays may increase the total duration of treatment or unnecessary use of broad-spectrum antimicrobials (Pyörälä, 2002; Barkema et al., 2006). Furthermore, due to challenges in consistently reliable interpretation of culture plates, considerable performance variation is possible between diagnostic laboratories, even if they follow standardized procedures. For example, in a proficiency study involving 40 Finnish laboratories, the overall rate of correctly 
identified mastitis bacteria ranged from 91 to only $63 \%$ (Pitkälä et al., 2005). An additional well-known problem of culture is that approximately 25 to $45 \%$ of all milk samples yield no bacterial growth even after $48 \mathrm{~h}$ of incubation (Makovec and Ruegg, 2003; Bradley et al., 2007; Koivula et al., 2007). Milk samples with no growth are costly and frustrating for the laboratory, for the veterinarian, and for the dairy producer.

Molecular methods have been suggested to alleviate some of the above-mentioned problems in IMI diagnostics since the 1990s (Oliver et al., 1998; Marcos et al., 1999). Real-time PCR technology has become a mainstay in clinical diagnostics (Bustin, 2004) but has yet to be implemented in mastitis testing routines. Many studies have reported on the development of PCR tests for the detection of IMI pathogens. The developed methods were capable of detecting only one or a few mastitis-causing microorganisms (Gillespie and Oliver, 2005; Graber et al., 2007) or information on their performance was based on PCR of culture isolates (Marcos et al., 1999; Riffon et al., 2001) or on a limited number of milk samples (Phuektes et al., 2001; Gillespie and Oliver, 2005; Taponen et al., 2009). In one study, Phuektes et al. (2001) reported on the development of a multiplex PCR assay for the detection of Staphylococcus aureus, Streptococcus agalactiae, Streptococcus dysgalactiae, and Streptococcus uberis and compared the test with conventional culture using 117 milk samples from subclinical mastitis. The results suggested significantly higher sensitivity of PCR compared with culture for detection of Staph. aureus and Strep. uberis.

In addition to the potential benefits, some challenges exist related to PCR testing of mastitis-causing bacteria. Approximately 140 different microbial species or subspecies have been isolated in bovine mastitis (Radostits, 2007). Although most of these have low prevalence, molecular methods can typically only target the species for which they have been designed, whereas in bacterial culture most species can potentially be identified. Furthermore, PCR methods are normally designed to identify genomic DNA instead of viable cells, and the clinical relevance of this difference awaits further evaluation (Schukken et al., 2010).

Recently, analytical accuracy was reported for a real-time PCR-based reagent kit capable of detecting 11 important IMI species/species groups (PathoProof Mastitis PCR Assay, Thermo Fisher Scientific, Espoo, Finland), based on a large collection of culture isolates (Koskinen et al., 2009). The objective of this study was to provide a performance comparison of the PCR test kit and conventional bacterial culture using 1,000 quarter milk samples taken from cows with clinical mastitis and subclinical mastitis, as well as from clinically healthy cows with a low SCC.

\section{MATERIALS AND METHODS}

\section{Samples}

Bovine milk samples were collected into sterile vials using routine aseptic sampling techniques from 1,000 udder quarters from 922 individual cows. The samples were taken by veterinarians, dairy consultants, or trained herd staff, and were collected as part of routine Finnish ( $\mathrm{n}=796$ quarter samples from 796 cows) and Dutch ( $\mathrm{n}=204$ quarter samples from 126 cows) mastitis control programs.

A total of 780 of the quarter milk samples were collected from cows with clinical mastitis (676 Finnish and 104 Dutch samples from 676 and 101 individual cows, respectively), defined according to the International Dairy Federation (IDF, 1999). The cows had clinical signs, including fever and inappetence, swelling, and pain in the affected udder quarter, and(or) physical changes of milk such as flakes, clots, or a watery appearance. These samples were defined as clinical samples.

In addition, 220 quarter milk samples (120 Finnish and 100 Dutch samples from 120 and 25 individual cows, respectively) were collected from clinically healthy cows with no visual signs of mastitis. Somatic cell counts were measured in these samples using a fluoro-optic cell counting method (Foss Electric, Hillerød, Denmark). Samples with an elevated SCC $(>250,000$ cells $/ \mathrm{mL})$ were considered to originate from cows with subclinical mastitis and were defined as subclinical samples (13 Finnish samples and 33 Dutch samples). Quarter milk samples with $\mathrm{SCC}<75,000$ cells/mL were considered to originate from healthy quarters and were defined as normal samples (93 Finnish samples and 39 Dutch samples). Samples with SCC above 75,000 but below 250,000 cells/mL (14 Finnish samples and 28 Dutch samples) were excluded from the analysis because of their ambiguous status regarding mastitis.

\section{Bacterial Culture}

Bacterial culture of the Finnish milk samples was performed at Valio Laboratories (Seinäjoki, Finland) and that of the Dutch samples at GD Animal Health Service (Deventer, the Netherlands). The samples were cultured on blood-esculin agar plates, following the standard procedures of the National Mastitis Council (Hogan et al., 1999); that is, $10 \mu \mathrm{L}$ of milk was streaked on the agar and incubated at $37^{\circ} \mathrm{C}$. Possible growth on the plates was examined after 18 to $24 \mathrm{~h}$ and again after $48 \mathrm{~h}$.

Laboratory operators did not perform species identification for samples where colonies representative of 3 or more species were growing on the plates. Such 
Table 1. The number of samples for which bacterial culture (BC) and the real-time PCR assay (PCR) provided negative results, or identified one or more bacterial species

\begin{tabular}{|c|c|c|c|c|c|c|}
\hline \multirow{2}{*}{$\begin{array}{l}\text { Species } \\
\text { detected, n }\end{array}$} & \multicolumn{2}{|c|}{$\begin{array}{l}\text { Samples from } \\
\text { clinical mastitis } \\
(\mathrm{n}=780)\end{array}$} & \multicolumn{2}{|c|}{$\begin{array}{c}\text { Samples from } \\
\text { subclinical mastitis } \\
\quad(\mathrm{n}=46)\end{array}$} & \multicolumn{2}{|c|}{$\begin{array}{l}\text { Samples from } \\
\text { healthy quarters } \\
(\mathrm{n}=132)\end{array}$} \\
\hline & $\mathrm{BC}$ & PCR & $\mathrm{BC}$ & PCR & $\mathrm{BC}$ & PCR \\
\hline 0 & 180 & 89 & 8 & 4 & 110 & 95 \\
\hline 1 & 475 & 318 & 37 & 27 & 20 & 30 \\
\hline 2 & 65 & 236 & 1 & 10 & 2 & 6 \\
\hline$\geq 3$ & 60 & 137 & - & 5 & - & 1 \\
\hline
\end{tabular}

samples are considered contaminated in routine mastitis testing (Hogan et al., 1999). Another practice routine in mastitis testing is that laboratory operators ignored the existence of sporadic colonies from common contaminating species such as Bacillus spp. or CNS if one primary species was clearly apparent on the streak.

\section{Real-Time PCR Assay}

A commercial real-time PCR test kit (PathoProof Mastitis PCR Assay, Thermo Fisher Scientific) was used for direct analysis of all milk samples; that is, without any bacterial culture steps. This testing procedure took approximately $4 \mathrm{~h}$. The Finnish samples were tested at Thermo Fisher Scientific (Espoo, Finland) and the Dutch samples at the Van Haeringen Laboratory (Wageningen, the Netherlands).

A total of $350 \mu \mathrm{L}$ of milk was used as the starting material for DNA extraction. The extraction protocol involved an enzymatic lysis step to disrupt the cell walls of gram-positive and gram-negative bacteria, as well as spin column-based DNA purification and elution steps.

The kit protocol involved 4 separate multiplex realtime PCR reactions, which targeted 11 bacterial species and groups (covering more than 25 mastitis-causing species in total): Staph. aureus, Staph. spp. (including Staph. aureus and all relevant CNS), Enterococcus spp. (including Enterococcus faecalis and Enterococcus faecium), Corynebacterium bovis, Escherichia coli, Strep. dysgalactiae, Strep. agalactiae, Strep. uberis, Arcanobacterium pyogenes/Peptoniphilus indolicus, Klebsiella spp. (including Klebsiella oxytoca and Klebsiella pneumoniae), and Serratia marcescens. The assay identified Staphylococcus spp., Enterococcus spp., and Klebsiella spp. to their species group levels; for example, all CNS were identified in the same real-time PCR reaction and instrument channel, and separation of different CNS species was not possible. Furthermore, A. pyogenes and $P$. indolicus were identified in the same real-time PCR reaction and channel.
The assay included internal amplification controls for confirmation of acceptable $\mathrm{PCR}$ reaction conditions. A negative control (distilled $\mathrm{H}_{2} \mathrm{O}$ ) was included in every PCR run to control for cross-contamination in the laboratory. Additional protocol details were identical to those described elsewhere (Koskinen et al., 2009).

\section{Comparison of the Tests}

All comparisons of bacterial culture and real-time PCR results were based on a double-blinded experimental design; that is, the culture results were not available to the PCR laboratory, and vice versa, before all laboratory work was finished.

Terminology for some of the bacterial species or groups differed between the tests, and the following results were considered comparable: Corynebacterium spp. in bacterial culture versus $C$. bovis results in PCR; $A$. pyogenes in bacterial culture versus $A$. pyogenes $/ P$. indolicus in PCR; and CNS in bacterial culture versus Staphylococcus spp. (staphylococci other than Staph. aureus) in PCR.

\section{RESULTS}

\section{Clinical Mastitis}

Conventional bacterial culture (48 h) identified one or more udder pathogens in 600/780 (77\%) quarter milk samples from clinical mastitis (Table 1). In comparison, real-time PCR identified bacteria in 691/780 (89\%) samples (Table 1). Hence, 23 and $11 \%$ of the clinical samples provided culture- and PCR-negative results, respectively (Table 1 ).

In total, $136 / 180(76 \%)$ culture-negative clinical samples gave positive results in real-time PCR (Table 2 ). The PCR analysis found several major mastitis bacteria (i.e., bacteria other than C. bovis or CNS) in these samples, including Staph. aureus $(\mathrm{n}=8)$, Strep. agalactiae $(\mathrm{n}=2)$, Strep. uberis $(\mathrm{n}=30)$, Strep. dysgalactiae $(\mathrm{n}=29)$, and E. coli $(\mathrm{n}=18)$ (Table 2$)$. A 
single bacterial species was found in PCR in 93/136 $(68 \%)$ of the culture-negative samples, 2 species were found in $31 / 136(23 \%)$ samples, and 3 or more species were found in 12/136 (9\%) of the samples. Coagulasenegative staphylococci, C. bovis, or both, were detected in all but one of the samples with 3 or more species; CNS occurred alone in 33 and C. bovis in 12 of the culture-negative samples. In 15 of the samples with 2 or more species, A. pyogenes / P. indolicus was detected in combination with Strep. dysgalactiae or with other streptococci or staphylococci. In total, PCR provided 217 bacterial identifications in the 136 culture-negative samples (Table 2).

When considering all 780 clinical samples, more bacteria, including major mastitis species, were found by using PCR than by culture (Table 3). For example, the PCR test detected Staph. aureus in 53 clinical samples and Strep. uberis in 137 clinical samples that were negative for these pathogens in culture (Table 3 ). The ability of the PCR test to detect more bacteria resulted in a higher number of samples in which multiple species were identified: in culture, 65 samples were interpreted to include 2 species and 60 samples had 3 or more species, whereas PCR detected 2 species in 236 samples and 3 or more species in 137 samples (Table 1). Altogether, bacterial culture provided 605 bacterial identifications across the clinical samples, whereas 1,247 bacterial identifications were made using PCR (Table 3). Coagulase-negative staphylococci, C. bovis, or both, were detected by PCR in 160/236 samples with 2 species and in $124 / 137$ samples with 3 or more species. Arcanobacterium pyogenes / P. indolicus was detected in $31 / 236$ samples containing 2 species and in 26/137 samples with 3 or more species.

Table 2. Bacterial species found in the clinical mastitis samples that provided negative results in culture, but positive results using the realtime PCR assay

\begin{tabular}{lc}
\hline Species detected & $\begin{array}{c}\text { No. of } \\
\text { samples }\end{array}$ \\
\hline Arcanobacterium pyogenes & $15(14)$ \\
Corynebacterium bovis & $39(27)$ \\
Enterococcus spp. & $4(3)$ \\
Escherichia coli & $18(9)$ \\
Klebsiella spp. & $2(1)$ \\
Staphylococcus aureus & $8(3)$ \\
CNS & $70(37)$ \\
Streptococcus agalactiae & $2(2)$ \\
Streptococcus dysgalactiae & $29(24)$ \\
Streptococcus uberis & $30(17)$ \\
\hline${ }^{1}$ A total of 136 samples from clinical mastitis provided negative results \\
in culture but positive results in PCR, in which these 217 bacterial \\
identifications were made. The total number of samples with the spe- \\
cies identification are indicated and, in parentheses, the number of \\
samples in which the bacteria were detected together with one or more \\
other species in the sample.
\end{tabular}

Journal of Dairy Science Vol. 93 No. 12, 2010
For most species, relatively good concordance was observed between culture and PCR results, except for a large number of cases in which PCR identified a species not detected in culture (Table 3). For example, for Staph. aureus, 82 samples had positive culture and PCR results, 12 samples had positive culture but negative PCR results, and 53 samples had positive PCR but negative culture results (Table 3 ). In bacterial culture, species identification was not attempted when colonies from 3 or more species were apparent on the streak; such samples were considered contaminated. When all PCR results with 3 or more species were excluded, the number of PCR-positive/culture-negative cases decreased (from a total of 780 to 419), but the number of culture-positive/PCR-negative cases increased (from a total of 94 to 190), and the number of samples with the same species identification decreased (from a total of 467 to 371 ; Table 3 ).

Across all 780 samples from clinical mastitis, culture identified 44 microorganisms that were not targeted or directly comparable by the PCR test. These included Bacillus spp. $(\mathrm{n}=10)$, Enterobacter spp. $(\mathrm{n}=3)$, gram-negative rods $(\mathrm{n}=6)$, Lactococcus spp. $(\mathrm{n}=4)$, Proteus spp. $(\mathrm{n}=1)$, Pseudomonas spp. $(\mathrm{n}=2)$, Streptococcus bovis $(\mathrm{n}=3)$, Streptococcus spp. $(\mathrm{n}=8)$, and yeast $(\mathrm{n}=7)$.

\section{Subclinical Mastitis}

Across the 220 samples collected from cows with no clinical signs of mastitis, 46 originated from quarters with subclinical mastitis (i.e., with increased milk SCC). The milk SCC of the subclinical samples varied between 296,000 and 4,011,000 cells $/ \mathrm{mL}$ (average = 778,000 cells $/ \mathrm{mL}$ ). Standard bacterial culture provided a positive bacterial identification for $38(83 \%)$ of the subclinical samples; 42 (91\%) samples were positive by PCR (Table 1).

Again, PCR detected multiple species in a larger number of samples than culture: in culture, only 1 subclinical sample contained 2 species, whereas PCR detected 2 species in 10 samples and 3 or more species in 5 samples (Table 1). Coagulase-negative staphylococci, C. bovis, or both, were detected in PCR in 9/10 samples with 2 species and in all 5 samples with 3 or more species.

The PCR test detected all of the bacterial species identified in culture in all subclinical samples, except for one case (Table 4). In total, culture provided 39 bacterial identifications across the subclinical samples and PCR provided 63 identifications (Table 4).

When PCR results from samples with 3 or more bacterial identifications were excluded, the total number of culture-positive/PCR-positive cases decreased from 
Table 3. The total number of bacteria found in bacterial culture (BC) and in real-time PCR (PCR) across the 780 samples from clinical mastitis

\begin{tabular}{|c|c|c|c|c|}
\hline \multirow[b]{2}{*}{ Species found $^{1}$} & \multicolumn{4}{|c|}{ Samples from clinical mastitis $(\mathrm{n}=780)^{2}$} \\
\hline & $\begin{array}{l}\text { BC pos / } \\
\text { PCR pos }\end{array}$ & $\begin{array}{l}\text { BC pos / } \\
\text { PCR neg }\end{array}$ & $\begin{array}{l}\text { BC neg / } \\
\text { PCR pos }\end{array}$ & $\begin{array}{l}\text { BC neg / } \\
\text { PCR neg }\end{array}$ \\
\hline \multicolumn{5}{|c|}{ All bacteria identified in culture and PCR } \\
\hline Arcanobacterium pyogenes & 12 & 1 & 50 & 717 \\
\hline Corynebacterium bovis & 33 & 10 & 172 & 565 \\
\hline Enterococcus spp. & 6 & 8 & 33 & 733 \\
\hline Escherichia coli & 54 & 10 & 68 & 648 \\
\hline Klebsiella spp. & 11 & 1 & 11 & 757 \\
\hline Staphylococcus aureus & 82 & 12 & 53 & 633 \\
\hline CNS & 131 & 33 & 185 & 430 \\
\hline Streptococcus agalactiae & 1 & 0 & 3 & 776 \\
\hline Streptococcus dysqalactiae & 65 & 8 & 67 & 636 \\
\hline Streptococcus uberis & 71 & 10 & 137 & 560 \\
\hline Serratia marcescens & 1 & 1 & 1 & 777 \\
\hline Total & 467 & 94 & 780 & 7,232 \\
\hline \multicolumn{5}{|c|}{ Excluding all PCR results from samples with $\geq 3$ species } \\
\hline Arcanobacterium pyogenes & 11 & 2 & 25 & 742 \\
\hline Corynebacterium bovis & 25 & 18 & 97 & 640 \\
\hline Enterococcus spp. & 4 & 10 & 9 & 757 \\
\hline Escherichia coli & 41 & 23 & 34 & 681 \\
\hline Klebsiella spp. & 4 & 8 & 3 & 765 \\
\hline Staphylococcus aureus & 72 & 22 & 35 & 651 \\
\hline CNS & 113 & 51 & 114 & 502 \\
\hline Streptococcus agalactiae & 1 & 0 & 0 & 779 \\
\hline Streptococcus dysqalactiae & 44 & 29 & 30 & 677 \\
\hline Streptococcus uberis & 55 & 26 & 71 & 628 \\
\hline Serratia marcescens & 1 & 1 & 1 & 777 \\
\hline Total & 371 & 190 & 419 & 7,599 \\
\hline
\end{tabular}

${ }^{1}$ In addition to the species listed, culture identified 44 microorganisms across the 780 samples from clinical mastitis that were not targeted or directly comparable by the PCR test. These included Bacillus spp. (n $=10)$, Enterobacter spp. (3), gram-negative rods $(\mathrm{n}=6)$, Lactococcus spp. $(\mathrm{n}=4)$, Proteus spp. $(\mathrm{n}=1)$, Pseudomonas spp. $(\mathrm{n}=2)$, Streptococcus bovis $(\mathrm{n}=3)$, Streptococcus $\mathrm{spp} .(\mathrm{n}=8)$, and yeast $(\mathrm{n}=7)$.

${ }^{2}$ Culture results with 3 or more species were considered contaminated and species identification was not attempted. These results are included in the BC negative (neg)/PCR positive (pos) or BC neg/PCR neg data. In the bottom half of the table, all samples where PCR detected 3 or more species were considered contaminated and, although the PCR assay provided results for all species in these samples, the results were excluded and the data are included in the BC pos/PCR neg or BC neg/PCR neg columns.

29 to 24 , culture-positive/PCR-negative cases increased from 1 to 6 , and culture-negative/PCR-positive cases decreased from 34 to 23 (Table 4).

Across the 46 sample from subclinical mastitis, culture identified 9 microorganisms not targeted or directly comparable by the PCR test. These included Bacillus spp. $(\mathrm{n}=3)$, gram-negative rods $(\mathrm{n}=2)$, Streptococcus spp. $(\mathrm{n}=3)$, and yeast $(\mathrm{n}=1)$.

\section{Healthy Quarters}

Twenty-two of the 132 milk samples (17\%) from clinically normal quarters with a low SCC were positive for mastitis bacteria in culture. In comparison, 37 samples (28\%) gave PCR positive results. Most of the positive results in culture and PCR occurred in the Dutch samples (18/39 and 30/39 positive samples in culture and PCR, respectively); only 4/93 (4.3\%) and
$7 / 93(7.5 \%)$ of the Finnish samples were positive in culture and PCR, respectively. A total of 24 bacterial identifications were done in the healthy samples in culture and 45 using PCR (Table 1). The major pathogens identified were E. coli ( $\mathrm{n}=2$ in PCR), Staph. aureus ( $\mathrm{n}=1$ in PCR), Strep. dysgalactiae ( $\mathrm{n}=1$ in PCR), Streptococcus spp. ( $\mathrm{n}=1$ in culture), and Strep. uberis $(\mathrm{n}=1$ in culture; $\mathrm{n}=2$ in PCR). All other bacteria detected in culture and PCR were minor pathogens $(C$. bovis or CNS).

\section{DISCUSSION}

Molecular methods hold promise for improving bovine IMI diagnostic tests for several reasons (Oliver et al., 1998: Marcos et al., 1999). First, in the case of acute clinical mastitis, shortened throughput time is a benefit of PCR compared with culture. Second, bacteriologi- 
Table 4. The total number of bacteria found in bacterial culture (BC) and in real-time PCR (PCR) across the 46 samples from subclinical mastitis

\begin{tabular}{|c|c|c|c|c|}
\hline \multirow[b]{2}{*}{ Species found ${ }^{1}$} & \multicolumn{4}{|c|}{ Samples from subclinical mastitis $(\mathrm{n}=46)^{2}$} \\
\hline & $\begin{array}{l}\text { BC pos / } \\
\text { PCR pos }\end{array}$ & $\begin{array}{l}\text { BC pos / } \\
\text { PCR neg }\end{array}$ & $\begin{array}{l}\text { BC neg / } \\
\text { PCR pos }\end{array}$ & $\begin{array}{l}\text { BC neg } \\
\text { PCR neg }\end{array}$ \\
\hline \multicolumn{5}{|c|}{ All bacteria identified by culture and PCR } \\
\hline Arcanobacterium pyogenes & 1 & 0 & 1 & 44 \\
\hline Corynebacterium bovis & 10 & 0 & 11 & 25 \\
\hline Enterococcus spp. & 1 & 0 & 0 & 45 \\
\hline Escherichia coli & 0 & 0 & 3 & 43 \\
\hline Klebsiella spp. & 0 & 0 & 0 & 46 \\
\hline Staphylococcus aureus & 1 & 0 & 2 & 43 \\
\hline CNS & 8 & 1 & 14 & 23 \\
\hline Streptococcus agalactiae & 0 & 0 & 0 & 46 \\
\hline Streptococcus dysgalactiae & 2 & 0 & 1 & 43 \\
\hline Streptococcus uberis & 6 & 0 & 2 & 38 \\
\hline Serratia marcescens & 0 & 0 & 0 & 46 \\
\hline Total & 29 & 1 & 34 & 442 \\
\hline \multicolumn{5}{|c|}{ Excluding all PCR results from samples with $>3$ species } \\
\hline Arcanobacterium pyogenes & 1 & 0 & 0 & 45 \\
\hline Corynebacterium bovis & 10 & 0 & 7 & 29 \\
\hline Enterococcus spp. & 1 & 0 & 0 & 45 \\
\hline Escherichia coli & 0 & 0 & 3 & 43 \\
\hline Klebsiella spp. & 0 & 0 & 0 & 46 \\
\hline Staphylococcus aureus & 0 & 1 & 1 & 44 \\
\hline CNS & 7 & 2 & 10 & 27 \\
\hline Streptococcus agalactiae & 0 & 0 & 0 & 46 \\
\hline Streptococcus dysgalactiae & 1 & 1 & 1 & 43 \\
\hline Streptococcus uberis & 4 & 2 & 1 & 39 \\
\hline Serratia marcescens & 0 & 0 & 0 & 46 \\
\hline Total & 24 & 6 & 23 & 453 \\
\hline
\end{tabular}

${ }^{1}$ In addition to the species listed, culture identified 9 microorganisms across the 46 samples from subclinical mastitis that were not targeted or directly comparable by the PCR test. These included Bacillus spp. $(\mathrm{n}=3)$, gram-negative rods $(\mathrm{n}=2)$, Streptococcus spp. $(\mathrm{n}=3)$, and yeast $(\mathrm{n}=1)$.

${ }^{2}$ Culture results with 3 or more species were considered contaminated and species identification was not attempted. These results are included in the BC negative (neg)/PCR positive (pos) or BC neg/PCR neg data. In the bottom half of the table, all samples where PCR detected 3 or more species were considered contaminated and, although the PCR assay provided results for all species in these samples, the results were excluded and the data are included in the $\mathrm{BC}$ pos/PCR neg or BC neg/PCR neg columns.

cal identification of mastitis-causing microorganisms is challenging because of the large number of species involved (Pitkälä et al., 2005). In PCR, interpretation of results can be objective and automated, and it may be easier to reach high accuracy in all diagnostic laboratories. Third, the high number of no-growth results is a drawback of bacterial culture, and PCR may offer an improvement with such samples (Taponen et al., 2009). In addition to benefits, molecular methods can have disadvantages compared with culture. One concern is that PCR methods are limited to detecting only the bacterial species for which a test kit has been designed. In culture, most species could potentially be identified. In addition, the clinical relevance of detecting bacterial nucleic acids instead of viable cells should be evaluated.

In our study, one advantage of the PCR kit used was its speed: both test laboratories involved had an approximate throughput time of $4 \mathrm{~h}$ from a milk sample to the final result (variation from 3 to $5 \mathrm{~h}$, depending on how many samples were analyzed per session). In practice, this analysis time provides the veterinarian and the dairy producer a same-day result instead of the current 24 to $48 \mathrm{~h}$ (sometimes even $72 \mathrm{~h}$ ) enabled by culture. Fast results can improve mastitis management and reduce cost due to improved treatment strategy and outcome (Pyörälä, 2002; Barkema et al., 2006), optimally leading to reduced use of antimicrobials and decreased amount of milk unfit for human consumption.

The PCR test improved the detection of mastitis bacteria in milk samples that yielded no-growth results in conventional culture, with $76 \%$ of culture-negative samples from clinical mastitis being positive in PCR. Although most these cases involved minor mastitis pathogens, a large number of major pathogens were detected by PCR in the clinical samples that were negative for the species in culture. For example, Staph. 
aureus was detected by PCR in $7.7 \%$ of all clinical samples that were Staph. aureus-negative in culture.

Staphylococcus aureus is one of the most prevalent etiological agents of chronic clinical and subclinical mastitis. The sensitivity of conventional culture in detection of Staph. aureus has not always been satisfactory (Godden et al., 2002). Improved sensitivity and speed of PCR in detecting Staph. aureus is important, because the pathogen, and certain clones in particular, can rapidly spread throughout the herd if management precautions are not taken (Sommerhäuser et al., 2003). Furthermore, Staph. aureus damages milk-producing tissue and significantly decreases milk yield (Zecconi et al., 2006). In the early stages of IMI, damage may be reversible and it is advantageous to diagnose the pathogen rapidly and with sensitivity. It is important to realize that Staph. aureus is a common inhabitant of the skin, and precautions should be taken to avoid this source of contamination when sampling the cow (Haveri et al., 2008).

Several reasons can limit the sensitivity of conventional culture. A low concentration of bacteria can lead to a no-growth result. Depending on the handling of the sample following collection of the milk from the quarter, the outcome of bacterial culture may vary. For example, Staph. aureus and Strep. agalactiae were detected at the highest number of colony forming units per milliliter of milk when the samples were frozen before culture (Godden et al., 2002). Other factors relating to laboratory protocols, such as the expertise of the technician and the duration of incubation, can affect the sensitivity of culture.

In conventional mastitis bacteriology, samples with 3 or more species should be considered contaminated, and resampling of the cows should be recommended by the laboratory. As PCR resulted in a higher number of such samples, its use would lead to an increased need for resampling when applying the current recommendations. This issue could be overcome by decreasing the detection limit of the PCR test; for example, by using less milk for DNA extraction, or by lowering the cycle threshold $(\mathrm{Ct})$ value at which a positive result is obtained. For example, decreasing the detection threshold to $\leq 30$ would decrease the number of clinical samples with 3 or more species from 137 to only 6 (data not shown). Such a strategy would decrease the sensitivity of the PCR test for species such as Staph. aureus or Strep. agalactiae where high sensitivity may be advantageous. As the real-time PCR technology enables accurate quantification of the targeted species, we propose that quantification of bacterial DNA be used routinely. This could allow the development of interpretation logic where only the species present in the highest quantities would be reported, except in the case of major mastitis pathogens. This important aspect of the PCR testing clearly requires further study. It would be useful to assess whether species present in the highest quantity in real-time PCR are the same as those found in bacterial culture.

In our study, we found 94 cases in which culture identified a species not detected by PCR. One explanation for the culture-positive/PCR-negative cases is that the "false-negative" PCR results were due to incorrectly identified species in culture. Laboratories performing routine mastitis diagnostics had approximately 9 to $37 \%$ incorrectly identified bacteria (Pitkälä et al., 2005); thus, this explanation could be applicable in our study.

Methods based on PCR are very sensitive and capable of detecting low bacterial copy numbers. In the case of mastitis, it could be argued that they are too sensitive, returning positive results for samples from cows free from IMI. This is true for all bacteriological methods, even when applying the recommended aseptic sampling techniques (NMC, 2004); a milk sample can always be contaminated from the teat orifice or environment. Consequently, in the case of IMI, bacteriological testing should always be interpreted with all available information, such as the history of the cow, clinical signs, and milk SCC. In our study, the concern of false-positive PCR results was compared with culture by testing quarter milk samples originating from clinically healthy cows with a low milk SCC. Across the samples collected from Finland, a similarly high number of negative results were observed in PCR and culture (92 and 96\%, respectively). A much higher number of positive results was detected both in culture and in PCR in the Dutch samples originating from quarters with a low milk SCC. The Dutch samples were taken randomly from cows with no clinical signs and the herds were not preselected based on their mastitis history, perhaps explaining the differences between the 2 data sets.

In this study, we found 780 cases (in samples from clinical mastitis) in which a bacterial species was not detected in culture but was identified by PCR. In PCR, all species present in the samples were always identified. Even when all samples with 3 or more species detected by PCR were removed from the PCR results, there was still a high number of cases (419) in which a species not detected in culture was detected by PCR. The analytical specificity of the PCR test was $100 \%$ based on an extensive bacterial strain collection, representing 83 species originating from 6 countries across Europe and North America (Koskinen et al., 2009). Such data attest that it is unlikely that the PCR test would deliver an erroneous positive signal if DNA from the respective microorganism is absent in the sample. Instead, when such a high level of analytical accuracy is combined 
with the results obtained for the milk samples from healthy animals, our conclusion for the PCR-positive but culture-negative samples from clinical mastitis is that culture provided false-negative results. It is important to note that although culture is capable of detecting only viable cells, the PCR test targets DNA and will identify both viable and nonviable organisms. Hence, the clinical relevance of PCR-positive/culturenegative results requires further study.

Concerning a diagnostic method, it can be useful to identify the bacteria responsible for IMI even if the bacteria are already dead. Such quarters do not require antibiotic treatment, but they can provide information on bacteriological etiology. Again, this highlights the importance of combining all available data, including diagnostic results, history, and clinical data of the cow before making management decisions. If required, technology exists for detection of only viable bacterial cells using PCR. One strategy is RNA amplification using reverse transcription-PCR (Keer and Birch, 2003). More recently, ethidium monoacide was reported to intercalate into double-stranded DNA and then irreversibly cross-link to the nucleic acids following photoactivation. The dye was thus excluded from viable cells due to its inability to pass through biological membranes and viable bacteria could be enumerated by real-time PCR once free DNA from dead cells was inactivated (Nocker et al., 2006).

In conclusion, the first comprehensive clinical field comparison has been provided of a PCR test kit and conventional bacteriology for identification of IMI pathogens. The PCR kit provided several benefits over conventional culture, including speed, objective and automated interpretation of results, and increased sensitivity in bacterial detection. Thus, PCR testing holds much promise as a tool to complement traditional methods in mastitis diagnostics. Further study is required to investigate how the high sensitivity of PCR can be used to improve the detection of major mastitis bacteria, without resulting in increased demand for resampling due to suspected contamination. Furthermore, because we found several cases where culture identified a species not targeted by the PCR test, it would be advantageous to increase the number of species detected by the PCR test.

\section{ACKNOWLEDGMENTS}

We thank Valio Laboratories (Seinäjoki, Finland) for providing the Finnish clinical samples and bacterial culture results for the study and Petri Backlund (Vetcare $\mathrm{Oy}$, Finland) for providing the Finnish samples from healthy quarters with low SCC.

\section{REFERENCES}

Barkema, H. W., Y. H. Schukken, and R. N. Zadoks. 2006. The role of cow, pathogen, and treatment regimen in the therapeutic success of bovine Staphylococcus aureus mastitis. J. Dairy Sci. 89:18771895.

Bradley, A. J., K. A. Leach, J. E. Breen, L. E. Green, and M. J. Green. 2007. Survey on the incidence and aetiology of mastitis on dairy farms in England and Wales. Vet. Rec. 160:253-257.

Bustin, S. A. 2004. An A-Z Manual of Quantitative PCR. IUL Press, La Jolla, CA.

Gillespie, B. E., and S. P. Oliver. 2005. Simultaneous detection of mastitis pathogens Staphylococcus aureus, Streptococcus uberis, and Streptococcus agalactiae by multiplex real-time polymerase chain reaction. J. Dairy Sci. 88:3510-3518.

Godden, S. M., J. T. Jocelyn, K. E. Leslie, N. L. Smart, and D. F. Kelton. 2002. Effect of sampling time and sample handling on the detection of Staphylococcus aureus in milk form quarters with subclinical mastitis. Can. Vet. J. 43:38-42.

Graber, H. U., M. G. Casey, J. Naskova, A. Steiner, and W. Schaeren. 2007. Development of a highly sensitive and specific assay to detect Staphylococcus aureus in bovine mastitic milk. J. Dairy Sci. 90:4661-4669.

Halasa, T., M. Nielen, A. P. De Roos, R. Van Hoorne, G. de Jong, T. J. Lam, T. van Werven, and H. Hogeveen. 2009. Production loss due to new subclinical mastitis in Dutch dairy cows estimated with a test-day model. J. Dairy Sci. 92:599-606.

Haveri, M., M. Hovinen, A. Roslöf, and S. Pyörälä. 2008. Molecular types and genetic profiles of Staphylococcus aureus isolated from bovine intramammary infection and extramammary sites. J. Clin. Microbiol. 46:3728-3735.

Hogan, J. S., R. N. Gonzalez, R. J. Harmon, S. C. Nickerson, S. P. Oliver, J. W. Pankey, and K. L. Smith. 1999. Laboratory Handbook on Bovine Mastitis. Rev. ed. National Mastitis Council, Madison, WI.

International Dairy Federation. 1999. Suggested interpretation of mastitis terminology. International Dairy. Fed. Bull. 338:3-26.

Keer, J. T., and L. Birch. 2003. Molecular methods for assessment of bacterial viability. J. Microbiol. Methods 53:175-183.

Koivula, M., E. A. Mäntysaari, A. Pitkälä, and S. Pyörälä. 2007. Distribution of bacteria and seasonal and regional effects in a new database for mastitis pathogens in Finland. Acta Agric. Scand. A 57:89-96.

Koskinen, M. T., J. Holopainen, S. Pyörälä, P. Bredbacka, A. Pitkälä, H. W. Barkema, R. Bexiga, J. Roberson, L. Sølverod, R. Piccinini, D. Kelton, H. Lehmusto, S. Niskala, and L. Salmikivi. 2009. Analytical specificity and sensitivity of a real-time polymerase chain reaction assay for identification of bovine mastitis pathogens. J. Dairy Sci. 92:952-959.

Makovec, J. A., and P. L. Ruegg. 2003. Results of milk samples submitted for microbiological examination in Wisconsin from 1994 to 2001. J. Dairy Sci. 86:3466-3472.

Marcos, J. Y., A. C. Soriano, M. S. Salazar, C. H. Moral, S. S. Ramos, M. S. Smeltzer, and G. N. Carrasco. 1999. Rapid identification and typing of Staphylococcus aureus by PCR-restriction fragment length polymorphism analysis of the aroA gene. J. Clin. Microbiol. 37:570-574.

National Mastitis Council. 1996. Current Concepts of Bovine Mastitis. 4th ed. NMC, Madison, WI.

National Mastitis Council. 2004. Microbiological Procedures for the Diagnosis of Bovine Udder Infection and Determination of Milk Quality. 4th ed. NMC, Madison, WI.

Nocker, A., C. Cheung, and A. K. Camper. 2006. Comparison of propidium monoazide with ethidium monoazide for differentiation of live vs dead bacteria by selective removal of DNA from dead cells. J. Microbiol. Methods 67:310-320.

Oliver, S. P., B. E. Gillespie, and B. M. Jayarao. 1998. Detection of new and persistent Streptococcus uberis and Streptococcus dysgalactiae intramammary infections by polymerase chain reactionbased DNA fingerprinting. FEMS Microbiol. Lett. 160:69-73. 
Phuektes, P., P. D. Mansell, and G. F. Browning. 2001. Multiplex polymerase chain reaction assay for simultaneous detection of Staphylococcus aureus and streptococcal causes of bovine mastitis. J. Dairy Sci. 84:1140-1148.

Pitkälä, A., V. Gindonis, H. Wallin, and T. Honkanen-Buzalski. 2005. Interlaboratory proficiency testing as a tool for improving performance in laboratories diagnosing bovine mastitis. J. Dairy Sci. 88:553-559.

Pyörälä, S. 2002. New strategies to prevent mastitis. Reprod. Domest. Anim. 37:211-216.

Radostits, O. M. 2007. Diseases of the Mammary Gland. Pages 673728 in Veterinary Medicine. 10th ed. O. M. Radostits, C. C. Gay, K. W. Hinchcliff, and P. D. Constable, ed. Elsevier Ltd., London, UK.

Riffon, R., K. Sayasith, H. Khalil, P. Dubreuil, M. Drolet, and L. Lagacé. 2001. Development of rapid and sensitive test for identification of major pathogens in bovine mastitis by PCR. J. Clin. Microbiol. 39:2584-2589.
Schukken, Y., P. Moroni, and R. N. Zadoks. 2010. Contribution of new technology to the improvement of milk quality and udder health on dairy farms. Mastitis Research Into Practice: Proceedings of the 5th IDF Mastitis Conference. VetLearn, Wellington, New Zealand.

Sommerhäuser, J., B. Kloppert, W. Wolter, M. Zschöck, A. Sobiraj, and K. Failing. 2003. The epidemiology of Staphylococcus aureus infections from subclinical mastitis in dairy cows during a control programme. Vet. Microbiol. 96:91-102.

Taponen, S., L. Salmikivi, H. Simojoki, M. T. Koskinen, and S. Pyörälä. 2009. Real-time polymerase chain reaction-based identification of bacteria in milk samples from bovine clinical mastitis with no growth in conventional culturing. J. Dairy Sci. 92:2610-2617.

Zecconi, A., L. Calvinho, and L. K. Fox, ed. 2006. Staphylococcus aureus intramammary infections. IDF Bull. 408:21-22. 